This article is distributed under the terms of the Creative Commons Attribution 3.0 PL (c) Copyright by Uniwersytet Warszawski Katedra Studiów Interkulturowych Europy Środkowo-Wschodniej \& individual articles to their Authors

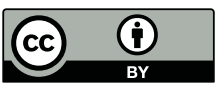

doi: 10.32612/uw.2543618X.2019.pp.449-478

Przegląd Środkowo-Wschodni, 4, 2019

ISSN 2543-618X elSSN 2545-1324

Nr art. 20190416

Data przesłania: 11.05 .2018

Data akceptacji: 23.05.2018

Андрэй Буча

Міжнародны гуманітарна-эканамічны інстытут buchaandrei@yandex.by

ORCiD: 0000-0002-2638-4909

\title{
Дзейнасць беларускіх прасавецкіх арганізацый у Чэхаславакіі ў 1920-я гады
}

\section{Działalność prosowieckich organizacji białoruskich w Czechosłowacji w latach 20. XX wieku}

W 1920 roku Praga została politycznym, intelektualnym, akademickim, naukowym i badawczym centrum Białorusinów za granicą. Kilkaset młodych Białorusinów pobierało naukę na czechosłowackich uczelniach wyższych, tu też żyli i pracowali politycy białoruscy. W latach 20. XX wieku dużą popularność wśród praskich Białorusinów zyskały idee smienowiechowstwa. W tym okresie w Pradze działało wiele prosowieckich organizacji białoruskich. Komunistyczna partia (bolszewików) Białorusi i przedstawiciel Związku Radzieckiego w Republice Czechosłowackiej skutecznie podtrzymywali nastroje prosowieckie wśród emigrantów białoruskich. Po ukończeniu studiów w Republice Czechosłowackiej większość członków stowarzyszeń białoruskich o orientacji sowieckiej przeniosła się do Białoruskiej SRR.

Słowa kluczowe: Czechosłowacja, diaspora białoruska, okres międzywojenny

Вывучэннем дзейнасці беларускіх прасавецкіх арганізацый у Чэхаславацкай Рэспубліцы (ЧСР) займаўся літаратуразнавец У. Калеснік ${ }^{1}$. Апошнюю сваю работу па гэтай праблематыцы ён апублікаваў у 1993 годзе. Пасля 1993 года новыя даследаванні,

${ }^{1}$ У. Калеснік, Ветразі Адысея, Мінск 1978; У. Калеснік, Пражскі эпісталярый [у:] Усё чалавечае: літаратурныя партрэты, Мінск 1993, с. 244-357. 
прысвечаныя дзейнасці беларускіх саветафільскіх арганізацый у Празе, больш не выходзілі. М. Чмарава, У. Ляхоўскі, А. Баршчэўскі, Д. Каляноўская, разглядаючы розныя аспекты жыцця беларускай дыяспары ў ЧСР, толькі часткова закраналі феномен пражскага беларускага зменавехаўства².

У гэтым артыкуле на аснове шырокага кола крыніц (непублікаваных раней архіўных матэрыялаў, перыядычных выданняў міжваеннага часу, прыватнай перапіскі і мемуараў), а таксама з улікам усіх папярэдніх гістарыяграфічных напрацовак зроблена спроба ахарактарызаваць дзейнасць беларускіх прасавецкіх арганізацый у ЧСР; высветліць, чаму зменавехаўскія ідэі заваявалі вялікую папулярнасць сярод беларусаў у ЧСР; паказаць ролю афіцыйнага Менска па развіцці руху прасавецкай арыентацыі сярод пражскіх беларусаў; прасачыць лёсы лідараў саветафільскіх арганізацый пасля іх вяртання на бацькаўшчыну.

\section{1-1924 гады: на шляху да інстытуцыяналізацыі} прасавецкага руху

Масавы прыезд беларусаў у Прагу трэба звязваць 3 пачаткам правядзення «Рускай акцыі» ${ }^{3}$ i выдзяленнем летам 1921 года 20 стыпендый для навучання беларусаў у вышэйшых школах ЧСР 4 .

${ }^{2}$ М. Чмарава, Шляхі ўзаемнага пазнання: беларуская літаратура ў Чэхаславакіi (1920-1945 г2.), Магілёў 2004; У. Ляхоўскі, Грамадска-культурная чыннасиь беларускай дыяспары ў Чэхаславакіi ў 1921-1938 г2. [у:] Ёсичь на карие месиа... Грамадска-культурная чьннасиьь беларускай $і$ расійскай эміграцылі у Чэхаславакіi. 1921-1938. Каталог, укл. Т. Воранава, Мінск 2002, с. 21-31; У. Ляхоўскі, Ад гоманаўиаў да гайсакоў. Чыннасиь беларускіх маладзёвых арганізацый у 2-й палове XIX cm. - 1939 г., Białystok, Vilnius 2012; А. Баршчэўскі, Беларуская эміграцьийная niсьмовасиь, Warszawa 2004; D. Kolenovská, Běloruská emigrace v Československu (1918-1939), „Soudobé dějiny” 2007, nr 1, s. 78-93.

${ }^{3}$ Праграма ўрада ЧСР па падтрымцы эміграцыі з былой Расійскай імперыі.

${ }^{4}$ Archiv Ministerstva zahraničních věcí České Republiky (AMZV), II Sekce politická, karton 241, č. 106650. 
Сярод тых, хто ў ліку першых па «беларускіх» стыпендыях прыехаў у ЧСР, былі Пётр Цветкаў і Ян Казімір Бабровіч. Менавіта гэтыя студэнты пачалі сярод беларускага зямляцтва папулярызацыю ідэй марксізму. Таму варта спыніцца на некаторых фактах з іх біяграфій.

П. Цветкаў ${ }^{5}$ скарэй за ўсё трапіў у лік беларускіх стыпендыятаў па рэкамендацыі ўрада Беларускай Народнай Рэспублікі. У Прагу прыехаў у верасні 1921 года для ўдзелу ў I Усебеларускай канферэнцыі. Восенню 1921 года стаў студэнтам хімічнага аддзяленння Пражскай політэхнікі. Паводле ўспамінаў В. Грышкевіча, П. Цветкаў быў «адумыслова прысланым палітруком з заданьнем наварачваньня на камунізм беларускіх студэнтаў у Празе» ${ }^{6}$.

Я. Бабровіч ${ }^{7}$ апынуўся ў Празе ў лютым 1922 года. Праўдападобна, Я. Бабровіч на вучобу быў накіраваны віленскім Таварыствам беларускай школы (ТБШ). Вясной 1922 года ён стаў студэнтам медыцынскага факультэта Карлавага ўніверсітэта.

Марксісты П. Цветкаў і Я. Бабровіч былі значна маладзейшыя за іншых беларускіх студэнцкіх лідараў. Так, у 1922 годзе П. Цветкаву было 23 гады, Я. Бабровічу - 20, Т. Грыбу і І. Дварчаніну - па 27, I. Ермачэнку - 28, Я. Станкевічу -31 .

Першыя беларускія стыпендыяты ${ }^{8}$ (тыя, хто трапіў у Прагу ў 1921 годзе) з'яўляліся пераважна навучэнцамі яшчэ дарэвалюцыйных расійскіх універсітэтаў, былі выхаваны ў рускай культурнай традыцыі. Таму гэтыя студэнты індыферэнтна ставіліся да беларускага нацыянальнага руху, адчувалі сябе «рускімі», былі інтэграваны ў жыццё рускай эміграцыі ў Празе. 3 канца 1921 года

${ }^{5}$ Пётр Цветкаў (2 лютага 1899 - ?), адзін з кіраўнікоў беларускага прасавецкага руху ў ЧСР. Нарадзіўся ў Дзвінску (цяпер Даўгаўпілс). У 1926 г. скончыў Пражскую політэхніку. У 1927 ці 1928 годзе выехаў з ЧСР у Польшчу. Далейшы лёс невядомы.

${ }^{6}$ Р. Жук-Грышкевіч, Жыц̧ьцеё Віни̧энта Жук-Грышкевіча, Toronto 1993, с. 48.

${ }^{7}$ Ян Казімір Бабровіч (2 чэрвеня $1902-8$ студзеня 1943), адзін з кіраўнікоў беларускага прасавецкага руху ў ЧСР, дзеяч рэвалюцыйнага руху ў Заходняй Беларусі.

${ }^{8}$ У. Ляхоўскі назваў іх студэнтамі-касмапалітамі. 
ў Прагу па накіраванні ТБШ сталі масава прыязджаць нацыянальна свядомыя юнакі і дзяўчаты з Заходняй Беларусі (у асноўным выпускнікі заходнебеларускіх гімназій).

Летам 1922 года паміж нацыянальна-свядомымі студэнтамі, якія к таму часу складалі большасць, і студэнтамі-касмапалітамі пачаліся спрэчкі. Не жадаючы падпарадкоўвацца пастановам большасці, сем студэнтаў-касмапалітаў (у тым ліку П. Цветкаў і Я. Бабровіч), якія вучыліся на «беларускіх» стыпендыях і знаходзіліся пад апекай Чэшска-ўкраінскага камітэта па аказанні дапамогі ўкраінскім і беларускім студэнтам (ЧУК), у чэрвені 1922 года перайшлі ў Камітэт па забеспячэнні адукацыі рускіх студэнтаў у ЧСР (КЗАРС). Такім чынам, беларуская грамада ў выніку гэтага канфлікту страціла такія важныя для беларусаў стыпендыі.

Марксісты П. Цветкаў і Я. Бабровіч, якія справакавалі канфлікт сярод беларускіх стыпендыятаў, нягледзячы на пераход у КЗАРС, і надалей заставаліся ангажаванымі ў грамадска-палітычнае жыццё беларускай дыяспары, бо ад членства ў Беларускай грамадзе ў Празе яны не адмовіліся.

Але актыўнасць П. Цветкава і Я. Бабровіча ў 1921-1923 гадах амаль не ўплывала на расстаноўку палітычных сіл у беларускай дыяспары. У гэты час прыхільнікі камуністычнай ідэалогіі заставаліся абсалютнай меншасцю і знаходзіліся на ўзбочыне грамадска-палітычнага жыцця беларускай дыяспары, а асноўныя ідэалагічныя разыходжанні паміж пражскімі беларусамі тычыліся выбару шляхоў і метадаў дасягнення незалежнасці ў форме БНР. Беларуская грамада была падзелена на прыхільнікаў левасацыялістычных і ліберальна-дэмакратычных поглядаў9.

У сакавіку 1923 года левасацыялістычная моладзь на чале 3 Т. Грыбам выйшла са студэнцкай секцыі пры Беларускай гра-

\footnotetext{
${ }^{9}$ Студэнты правых поглядаў на чале з Я. Станкевічам у канцы 1922 года стварылі Беларускі сялянскі саюз у Празе.
} 
мадзе $(\text { ССБГ })^{10}$ у Празе і ўтварыла сваю самастойную арганізацыю - Аб'яднанне беларускіх паступовых студэнтаў (АБПС). АБПС уяўляла сабой не цэласную і маналітную структуру, а скарэй было дэмакратычнай платформай левых сіл, вакол якой аб'ядноўваліся эсэры, нацыянал-камуністы, марксісты.

3 сакавіка 1923 года у складзе АБПС пачаў дзейнічаць марксісцкі гурток, створаны па ініцыятыве П. Цветкава і Я. Бабровіча ${ }^{11}$. Галоўнай мэтай марксістаў з'яўлялася паглыбленне ведаў у галіне навуковага сацыялізму сярод беларускіх студэнтаў. На пасяджэннях марксісцкага гуртка заслухоўваліся рэфераты, падрыхтаваныя сябрамі арганізацыі. У абмеркаванні рэфератаў прымалі ўдзел таксама студэнты са студэнцкай секцыі ${ }^{12}$. Агульную дзейнасць марксістаў каардынаваў П. Цветкаў.

Сябры АБПС не маглі прыйсці да кансэнсусу ў справе таго, хто павінен узначаліць змаганне за незалежнасць Беларусі, вакол якой палітычнай сілы трэба аб'ядноўвацца. Значная частка сяброў на чале з В. Русаком і В. Грышкевічам арыентаваліся на ўрад БНР. Эсэры на чале з Т. Грыбам, адмаўляючы законнасць урада А. Цвікевіча, а таксама савецкі шлях пабудовы беларускай дзяржаўнасці, сфармулявалі тэорыю так званай «трэцяй сілы», якая ў барацьбе на два франты (супраць палякаў і бальшавікоў) павінна дамагчыся незалежнасці Беларусі.

Група сяброў АБПС на чале з І. Дварчаніным і У. Жылкам больш рэалістычна ацэньвала тагачасную сітуацыю і разумела неабходнасць пошуку саюзніка ў змаганні за ідэалы незалежнасці. Яны станоўча ацэньвалі культурныя дасягненні ў Савецкай Беларусі. Аднак у другой палове 1923 - першай палове 1924 года ў адносінах да БССР «рэалісты» займалі пазіцыю чакання. Так, напрыклад, рэдак-

${ }^{10}$ Апалітычная арганізацыя, у склад якой уваходзілі беларускія студэнты, якія знаходзіліся на ўтрыманні ЧУК.

${ }^{11}$ У. Ляхоўскі, Беларускія студэниякія арганізацыьі ў Чэхіі [у:] Энцьыклапедыя гісторыі Беларусі. У 6 т. Т. 6. Кн. 2, Мінск 2003, с. 340.

${ }^{12}$ Хроніка, «Перавясла» 1923, № 1, с. 61. 
тар перыядычнага органа АБПС «Перавясла» У. Жылка ў жніўні 1923 года яшчэ не ўяўляў Менск цэнтрам па аб’яднанні беларускіх зямель і супрацьпастаўляў яму Вільню ${ }^{13}$.

Кіраўнікі марксісцкага гуртка П. Цветкаў і Я. Бабровіч галоўны акцэнт рабілі на праблеме сацыяльнага вызвалення беларускага народа, прычым падкрэслівалі кіруючую ролю пралетарыяту ў гэтым працэсе і нігілістычна ставіліся на нацыянальнага пытання ${ }^{14}$. Менавіта нігілізм у нацыянальным пытанні кіраўнікоў марксісцкага гуртка адштурхоўваў ад іх нацыянальна арыентаваную беларускую моладзь левых поглядаў. У лістападзе 1923 года I. Дварчанін пісаў У. Жылку: «Я са сваімі марксістамі парваў і, відаць, аканчальна, па крайняй меры, рашуча. За іх маскальшчыну. Так што ўжо больш не трэба прасіць вярнуць слова назад: застаўся самім сабою, адзін, як палец» ${ }^{15}$.

Тым не менш, дзякуючы напорыстасці сваіх кіраўнікоў, марксісты былі прадстаўлены ў кіраўніцтве АБПС і Беларускай грамады ў Празе. Я. Бабровіча, які ў 1923 годзе ўступіў у Камуністычную партыю Чэхаславакіі (КПЧ), двойчы абіралі ў прэзідыум АБПС, дэлегавалі ад гэтай арганізацыі ў вучэбна-праверачную камісію ЧУК. М. Верамей займаў пасады скарбніка і намесніка старшыні Беларускай грамады ў Празе. М. Каўцэвіч уваходзіў у прэзідыум АБПС.

У сакавіку 1924 года, каб павялічыць колькасць рэфератаў і падняць іх навуковы ўзровень, беларускі марксісцкі гурток і Украінская сацыялістычная грамада аб'ядналі сваю культурна-асветную дзейнасць ${ }^{16}$. Гэта сведчыла пра збольшага індыферэнтнае стаўленне беларускіх студэнтаў да камуністычнай прапаганды. Падкрэслім яшчэ раз, што росту папулярнасці марксістаў сярод нацыянальна

${ }^{13}$ Лісты Уладзіміра Жылкі да Антона Луцчкевіча, публ., падрыхт. тэксту, камент. А. Сідарэвіча [у:] Шляхам гадоу: гісторыка-літаратурны зборнік, укл. Я. Янушкевіч, рэдкал.: Г. Кісялеў і інш., Мінск 1994, с. 24.

${ }_{14}$ У. Калеснік, Пражскі эпісталярый..., с. 282-283.

${ }^{15}$ У. Калеснік, Пражскі эпісталярый, «Полымя» 1990, № 9, с. 244.

${ }^{16}$ Хроніка, «Перавясла» 1924, № 2, с. 61. 
свядомай беларускай студэнцкай грамады перашкаджала дэклараванне нігілізму ў нацыянальным пытанні, а таксама дагматызм i нягнуткасць іх лідараў. Да першай паловы 1924 года прапагандысцкая дзейнасць марксісцкага гуртка не прывяла да радыкальнага змянення расстаноўкі палітычных сіл унутры дыяспары.

Чарговым разам марксісты актывізаваліся уу жніўні 1924 года падчас канферэнцыі па стварэнні Аб'яднання беларускіх студэнцкіх арганізацый (АБСА) - апалітычнай арганізацыі, якая павінна была аб'яднаць ідэалагічна неаднародную беларускую студэнцкую калонію. На гэтай канферэнцыі асноўная спрэчка адбылася паміж Я. Бабровічам і В. Грышкевічам. Першы даказваў, што існаванне апалітычнай прафесійнай арганізацыі немагчыма, што створанае аб'яднанне ўсё роўна будзе займацца палітыкай. Я. Бабровіч, заявіўшы, што выступае ад імя прасавецкі настроенага студэнцтва, быў абураны тым, што ў статуце АБСА не адлюстравана «выразнае адношанне да Польшчы і Савецкай Беларусі». У адказ на заўвагі Я. Бабровіча выступіў В. Грышкевіч. Ён паведаміў прысутным, што менавіта з-за адсутнасці прафесійнага саюза беларусы «церпяць на міжнародным полі». В. Грышкевіч таксама адзначаў, што «палітычная арганізацыя, якая аб'яднае ўсё беларускае студэнцтва, немагчыма, паколькі немагчыма адзіная ідэалогія». Заўвагі Я. Бабровіча дэлегаты адкінулі. У выніку, быў зацверджаны праект В. Грышкевіча, а Я. Бабровіч дэманстратыўна пакінуў памяшканне. Пад канец пасяджэння дэлегаты прынялі рэзалюцыю-пратэст супраць уціску і здзеку з беларускага насельніцтва ў Польшчы ${ }^{17}$.

Менавіта пасля правядзення беларускай студэнцкай канферэнцыі па стварэнні цэнтральнай студэнцкай арганізацыі прасавецкі настроеныя студэнты на чале з Я. Бабровічам, не пагадзіўшыся 3 апалітычным характарам новага аб'яднання, пачалі працу па заснаванні сваіх альтэрнатыўных арганізацый.

${ }^{17}$ Беларускі дзяржаўны архіў-музей літаратуры і мастацтва (БДАМЛіМ), ф. 3, воп. 1, спр. 181, арк. 35-37. 
Такім чынам, дыскусіі вакол выпрацоўкі агульных прынцыпаў статута АБСА адлюстравалі, з аднаго боку, кансалідацыю пэўнай часткі студэнцтва вакол ідэі прафесійнага саюза, а $з$ другога, пацвердзілі канчатковае адасабленне марксісцкага гуртка і пачатак арганізацыі прасавецкі настроеных студэнтаў.

Па сведчаннях К. Дуж-Душэўскага, які ў кастрычніку 1924 года наведаў Прагу, прыхільнікаў камуністаў на той момант сярод беларусаў было 14 чалавек, эсэраў на чале з Т. Грыбам - 31, студэнтаў правых поглядаў на чале з Я. Станкевічам -65 , іншыя заставаліся беспартыйнымі. Усяго ж у Празе ў той час вучыліся 350 беларускіх студэнтаў (з іх 150 на «беларускіх» стыпендыях $)^{18}$. Нават улічваючы пэўную суб'ектыўнасць гэтай крыніцы, відаць, што яшчэ ў канцы 1924 года беларускія студэнты-марксісты знаходзіліся ў меншасці.

\section{Погляд на Менск як на беларускі П’емонт}

Скарэй насуперак, чым дзякуючы актыўнай працы марксістаў адбывалася дыферэнцыяцыя дыяспары. Пробным каменем, які абумовіў ідэалагічнае размежаванне чэхаславацкіх беларусаў, стала бачанне шляхоў пабудовы незалежнай беларускай дзяржавы.

3 цягам часу ідэя па разуменні Менска як цэнтра па аб'яднанні беларускіх зямель станавілася уссё больш прывабнай для пражскіх беларусаў. Гэтаму спрыялі поспехі нацыянальна-культурнага будаўніцтва БССР (палітыка беларусізацыі, вяртанне БССР часткі ўсходніх беларускіх этнічных тэрыторый).

3 іншага боку, крызіс палітычных структур БНР, адкіданне Літвой «беларускай карты» пасля прызнання Канферэнцыяй паслоў усходніх граніц Польшчы ў сакавіку 1923 года (гэта азначала палітычную смерць Рады і уурада БНР), расчараванасць у магчы-

${ }^{18}$ Архівы Беларускай Народнай Рэспублікі. Т. 1. Кн. 2. Фонд № 582 Дзяржсайнага Архіву Літвы («Рада Міністраў Беларускай Народнай Рэспублікі»), укл. С. Шупа, Vilnius, New York, Мінск, Praha 1998, с. 1545. 
масці атрымання беларусамі нацыянальна-культурнай аўтаноміі ў Польшчы, сімпатыі значнай часткі нацыянальнага актыву Заходняй Беларусі да савецкага Менска (уяўленні пра БССР як пра асноўнага саюзніка ў барацьбе за правы беларускай меншасці ў Польшчы), стварэнне Беларускай сялянска-работніцкай грамады (БСРГ), ліквідацыя ў чэрвені 1924 года галоўнага палітычнага апанента бальшавікоў - Беларускай партыі сацыялістаў-рэвалюцыянераў таксама сталі значнымі фактарамі, якія прывялі да ідэалагічнай пераарыентацыі беларускай дыяспары ў Чэхаславакіi ${ }^{19}$.

Непрымірымы ідэйны вораг камуністаў Т. Грыб яшчэ да афіцыйнага пачатку палітыкі беларусізацыі, у маі 1923 года, пісаў У. Жылку, што хаця «за Менскам стаіць сіла варожая - там стаіць мардасты кацап, поўны злобы і нянавісці к „сепаратыстам”», «Менск станець беларускай галавой і сэрцам - адзіным цэнтрам - адзінай воляй», і што туды «мусяць быць сцягнуты ўсе сілы для пазітыўнай, культурнай і гаспадарчай працы, а таксама і для барацьбы» ${ }^{20}$.

Восенню 1924 года ў выніку ідэалагічных рознагалоссяў дужа стракатае АБПС распалася. Большая частка сяброў АБПС на чале з У. Жылкам і І. Дварчаніным заснавалі таварыства «Незалежнасць» ${ }^{21}$, частка ўвайшла ў склад «Адзінства рускай культуры» ${ }^{22}$.

${ }^{19}$ А. Ціхаміраў, Эміграцыля [у:] Энцыьклапедыя гісторыі Беларусі. У 6 m. Т. 6. Кн. 2, Мінск 2003, с. 257; AMZV, II Sekce politická, karton 450, č. 107866.

${ }^{20}$ У. Калеснік, Пражскі эпісталярый, «Полымя» 1990, № 10, с. 214.

${ }^{21}$ В. Лаўскі, 3 жыцьия беларускага студэнства на чужыне, «Студэнская думка» 1928, № 1, с. 22; Я. Місарэвіч, М. Каралёў, I. С. Дварчанін: гісторыкабіяграфічны нарыс, Гродна 1995, с. 298; А. А., Kryvickaje (Biełaruskaje) Kulturnaje Tawarystwa d-ra Franciška Skaryny, „Krynica” 1925, nr 28, s. 7.

22 Таварыства студэнтаў маларосаў і беларусаў «Адзінства рускай культуры» - эмігранцкая грамадска-палітычная арганізацыя ў ЧСР, якая аб'ядноўвала беларускую і ўкраінскую моладзь, што прытрымлівілася ідэалогіi заходнерусізму. Стварэннем арганізацыі займаліся руская эмігранцкая група (праф. Дз. Вяргун (1871-1951), філолаг, публіцыст, які з 1921 года жыў у Празе, студэнцкі саюз «Червонная Русь», Аб'яднанне рускіх эмігранцкіх студэнцкіх арганізацый). Таварыства было афіцыйна зацверджана 26 верасня 1924 года, 29 лістапада на 
«Вольная грамада» ${ }^{23}$ і гурток марксістаў, які атрымаў новую назву Марксісцкая група, працягвалі існаваць як самастойныя арганізацыі.

Таварыства «Незалежнасць» было культурна-асветным аб'яднаннем. Студэнты, згуртаваныя ў гэтай арганізацыі, станоўча ацэньвалі дзяржаўна-культурнае будаўніцтва ў Савецкай Беларусі. Лідары арганізацыі У. Жылка і І. Дварчанін усё больш схіляліся да думкі, што ў Менску рэалізуецца беларускі дзяржаўны праект. Частка сяброў «Незалежнасці» адначасова ўваходзіла ў склад Беларускай рады ў Празе.

Пасяджэнні «Незалежнасці», на якіх зачытваліся i абмярковўваліся рэфераты, адбываліся кожную суботу. Характар дзейнасці арганізацыі трапна ілюструе тэматыка рэфератаў, падрыхтаваных яе сябрамі: «Ірландскі вызваленчы рух і Беларусь» (І. Дварчанін), «Зямельнае пытанне і Беларусь» (А. Шах), «Крытычны агляд „Спадчыны” Я. Купалы», «Пяснярскі Менск» (У. Жылка, Л. Вернікоўская, М. Каберац $)^{24}$.

Таварыства «Незалежнасць» займала крытычную пазіцыю ў адносінах да «Адзінства рускай культуры», якое прапагандавала ідэалогію заходнерусізму, а таксама да Марксісцкай групы, кіраўніцтва якой ігнаравала нацыянальнае пытанне ${ }^{25}$. Кіраўнікі «Незалежнасці» У. Жылка і І. Дварчанін, улічваючы міжнародную сітуацыю, ужо не верылі ў магчымасць рэалізацыі ідэі беларускага суверэнітэту

ўстаноўчым сходзе быў абраны першы прэзідыум арганізацыі. У 1929 годзе адбылася змена назвы арганізацыі на Саюз маларосаў і беларусаў «Адзінства рускай культуры». Звестак пра дзейнасць саюза ў 1930-я гады няма.

${ }^{23}$ «Вольная грамада» - беларуска-ўкраінская арганізацыя эсэраў. Дзейнічала ў Празе з 1923 да канца 1920-х гадоў. Складалася $з$ дзвюх аўтаномных частак (беларускай і ўкраінскай). Беларускі бок у «Вольнай грамадзе» прадстаўляла група эсэраў на чале з Т. Грыбам. Асноўнай задачай «Вольнай грамады» было крытычнае вывучэнне і пазнанне ідэалогіі рэвалюцыйнага сацыялізму.

${ }^{24}$ Дабрасельскі, Беларуская калёнія у Празе-Чэшскай, «Сялянская ніва» 1926, № 3, с. 3; Лісты Уладзіміра ..., с. 36.

${ }_{25}^{25}$ Дабрасельскі, op. cit., с. 3; Я. Місарэвіч, М. Каралёў, оp. cit., с. 298. 
ў форме БНР. Па меркаванні У. Калесніка, яны ўяўлялі перспектыву беларускага нацыянальнага руху ў супрацоўніцтве левадэмакратычных сіл з патрыятычна настроенымі ўдзельнікамі камуністычнага руху як у БССР, так і ў Заходняй Беларусі ${ }^{26}$.

На нашу думку, адным 3 ключавых фактараў, які паспрыяў папулярызацыі прасавецкіх настрояў сярод беларусаў у ЧСР, стала мэтанакіраваная, актыўная i эфектыўная дзейнасць афіцыйнага Менска. Таму пры разглядзе пытання аб папулярызацыі ідэі савецкай дзяржаўнасці ў асяроддзі беларускай дыяспары ў Чэхаславакіі не варта скідваць з рахунку работу дзяржаўных органаў БССР па «развіцці беларускага руху савецкай арыентацыі» сярод беларускай палітычнай эміграцыі ${ }^{27}$.

У сувязі са знаходжаннем у Празе прадстаўнікоў урада БНР, беларускіх эсэраў на чале з Т. Грыбам і групы Я. Станкевіча кіраўніцтва БССР лічыла пражскі беларускі эміграцыйны цэнтр даволі ўплывовым і патэнцыяльна небяспечным. Значнасць пражскага асяродка была абумоўлена і канцэнтрацыяй вялікай колькасці беларускіх студэнтаў у вышэйшых школах ЧСР. Так, у 1922-1927 гадах у чэхаславацкіх універсітэтах навучалася больш заходнебеларускай моладзі, чым у ВНУ Польшчы. У 1920-я гады Прага з’яўлялася адным 3 найбольш уплывовых і буйных беларускіх акадэмічных цэнтраў, якія існавалі па-за межамі БССР.

Найбольшы інтарэс для савецкага Менска ўяўлялі сябры «Незалежнасці», г. зн. тыя беларускія студэнты, якія ў 1924 годзе пачалі з вялікай сімпатыяй глядзець у бок савецкага Менска, расчараваліся ў магчымасцях супрацоўніцтва 3 польскімі ўладамі ў Заходняй Беларусі, а таксама не прымалі нацыянальнага нігілізму лідараў марксістаў П. Цветкава і Я. Бабровіча.

${ }^{26}$ У. Калеснік, Пражскі эпісталярый..., с. 269.

${ }^{27}$ С. Траццяк, Рэвалюцыийная хваля беларускай эміграџьыі [у:] Гісторыя Беларусі. Т. 5. Беларусь у 1917-1945 г2., рэдкал.: М. Касцюк і інш., Мінск 2007, c. 137. 
Найбольшай небяспекай для кіраўніцтва БССР быў урад БНР, які з лістапада 1923 года знаходзіўся ў Празе і працягваў, хоць і чыста тэарэтычна, заставацца палітычнай і ідэалагічнай альтэрнатывай КП(б)Б.

Таму на 1925 год кіраўніцтва БССР намеціла наступныя задачы па працы сярод беларускай дыяспары ў ЧСР: 1) ліквідацыя ўрада БНР; 2) папулярызацыя прасавецкіх настрояў сярод беларускіх студэнтаў і заахвочванне іх пасля атрымання дыпломаў да выезду ў БССР.

Вырашальная «бітва» 1925 года: спроба прасавецкіх актывістаў узначаліць структуры беларускай дыяспары y̆ ЧСР

Вясной 1925 года на пасяджэнні Марксісцкай групы было вырашана заснаваць па ўзоры ўжо дзеючых саюзаў студэнтаў-грамадзян РСФСР і УССР Саюз студэнтаў-грамадзян БССР. Ініцыятыўная група (Г. Муха, М. Рагуля, Р. Тананко) правяла ўсю падрыхтоўчую работу па стварэнні і афіцыйным зацвярджэнні беларускага саюза. М. Каўцэвіч, як меркаваны старшыня арганізацыі, скантактаваўся 3 прадстаўніцтвам СССР у Празе і атрымаў інструкцыі па дзейнасці будучай арганізацыі ${ }^{28}$.

На арганізацыйным сходзе Саюза студэнтаў-грамадзян БССР, які адбыўся вясной 1925 года, была агучана галоўная мэта арганізацыі - «дапамога маладым людзям пасля сканчэння вучобы праз прадстаўніцтва СССР атрымаць савецкае грамадзянства і дазвол на ўезд у БССР». У прэзідыум саюза ўвайшлі М. Каўцэвіч (старшыня), Г. Муха (намеснік старшыні), М. Рагуля, Р. Тананко, М. Шыманка' 29. У маі 1925 года Саюз студэнтаў-грамадзян БССР быў зарэгістраваны як філіял Саюза студэнтаў-грамадзян УССР ${ }^{30}$.

\footnotetext{
${ }^{28}$ Г. Муха-Мухновский, Пути-дороги, Минск 1973, с. 92.

${ }^{29}$ Ibidem, c. 92-93.

${ }^{30}$ Л. Заяц, Беларусы у Чэхаславакіi, «Савецкая Беларусь» 1926, № 143, с. 2.
} 
Акрамя таго, па ініцыятыве Марксісцкай групы ў пачатку 1925 года былі арганізаваны тры гурткі па вывучэнні праблем марксізму, якія ўзначальвалі адпаведна беларускія студэнты П. Цветкаў, Я. Бабровіч, М. Верамей. У той жа час сябры Марксісцкай групы наладзілі працу па абмеркаванні актуальных тэм і ў Саюзе студэнтаў-грамадзян БССР ${ }^{31}$.

Нішу паміж апалітычнымі студэнтамі і Саюзам студэнтаў-грамадзян БССР займала неафіцыйная культурна-асветная арганізацыя «Грамада», якая знаходзілася пад ідэалагічным кантролем Марксіцскай групы ${ }^{32}$. На жаль, не ўдалося знайсці інфармацыю пра дакладную дату стварэння гэтай арганізацыі і выявіць асоб, якія прычыніліся да яе заснавання. Актыўную дзейнасць «Грамада» пачала праводзіць з восені 1925 года.

Стратэгічнай мэтай «Грамады» 3'яўлялася падрыхтоўка беларускіх студэнтаў да ўступлення ў Саюз студэнтаў-грамадзян БССР 33 . Сяброўскі склад «Грамады» ў большасці сваёй быў сфарміраваны за кошт былых членаў «Незалежнасці» (распалася вясной 1925 года $)^{34}$. Дзейнасць «Грамады» развівалася ў двух кірунках: 1) чытанне рэфератаў на сацыяльна-эканамічныя тэмы; 2) правядзенне курсаў. У 1925/1926 акадэмічным годзе на пасяджэннях «Грамады» было прачытана 15 рэфератаў на такія тэмы, як: «Творчасць Я. Купалы», «Заданні беларускай моладзі», «Расклад антысавецкай эміграцыі і берлінская нарада», «Сялянскае пытанне ў Заходняй Беларусі», «Сялянскі саюз і яго роля» і інш. Значнае месца адводзілася вывучэнню марксізму. Тэматыка рэфератаў, прадстаўленых на пасяджэннях арганізацыі, сведчыць пра яе большую палітызаванасць у параўнанні з таварыствам «Незалежнасць».

${ }^{31} \Gamma$. Муха-Мухновский, op. cit., c. 94-95.

32 Л. Заяц, ор. cit., с. 2; Идеологическая деятельность Компартии Белоруссии. 1918-1945. Сборник документов. Ч. 1, сост.: Н. С. Сташкевич, редкол.: Р. П. Платонов и др., Минск 1990, с. 192.

33 Эміграцыья, «Прамень» 1926, № 1, с. 30.

${ }^{34}$ A. A., op. cit., s. 7. 
Сур'ёзным фактарам, які абумовіў актыўнасць прасавецкі настроеных студэнтаў у 1925 годзе, стала фінансаванне іх дзейнасці з боку афіцыйнага Менска. Так, 5 мая 1925 года на закрытым пасяджэнні СНК БССР на развіццё руху прасавецкай арыентацыі сярод беларускіх арганізацый у Польшчы, Латвіі, Літве і Чэхаславакіі да канца бюджэтнага 1926 года было асігнавана 25 тысяч рублёӱз5.

31 ліпеня 1925 года ЦК КП(б)Б звярнуўся ў ЦК РКП(б) з праектам аб мэтазгоднасці ўвядзення ў апарат паўпрэдстваў СССР у Польшчы, Латвіi, Чэхаславакіі беларускіх работнікаў, адказных за працу з беларускімі арганізацыямі ў адзначаных краінах ${ }^{36}$. Беларускі прадстаўнік у Празе, акрамя іншага, павінен быў каардынаваць і накіроўваць дзейнасць прасавецкіх беларускіх студэнтаў у Празе. Дакументальных пацвярджэнняў гэтага знайсці не ўдалося. Але трэба думаць, што ў паўпрэдства СССР у ЧСР адправілі работніка, адказнага за працу з беларускай эміграцыяй ці, магчыма, гэты фронт работы быў даручаны камусьці са штатных супрацоўнікаў савецкага прадстаўніцтва ў Празе.

Часткай падрыхтоўчай работы афіцыйнага Менска перад беларускай канферэнцыяй у Берліне, на якой планавалася спыненне дзейнасці ўрада БНР, стаў візіт ў кастрычніку 1925 года ў Прагу дэлегацыі БССР у складзе 3. Жылуновіча, Я. Купалы, М. Чарота ${ }^{37}$. Беларускія пісьменнікі атрымалі дакладныя інструкцыі як сябе паводзіць у Празе, з кім сустракацца і пра што гаварыць. Гэта паездка была падрыхтавана па лініі ЦК КП(б)Б ${ }^{38}$. Самым аўтарытэтным членам дэлегацыі быў Я. Купала, але галоўная роля адводзілася 3. Жылуновічу.

35 Знешняя палітыка Беларусі. Зборнік дакументаў $і$ матэрыялаў. Т. 2, скл.: У. Міхнюк; рэдкал.: І. Антановіч і інш., Мінск 1999, с. 214-215.

${ }^{36}$ Ibidem, c. 157.

37 Л. Мирочицкий, Белорусско-чехословацкие культурные и научные связи, Минск 1981, с. 18.

38 Знешняя палітыка..., с. 166. 
Мэтай паездкі беларускіх пісьменнікаў было «наладжванне сувязі з прадстаўнікамі беларускай грамадскасці, якія цікавяцца культурнай працай Савецкай Беларусі», інфармаванне аб поспехах нацыянальнага будаўніцтва ў БССР, заахвочванне вяртання інтэлігенцыі на бацькаўшчыну ${ }^{39}$. Паводле ўспамінаў члена Марксісцкай групы Ю. Мухі, прадстаўнікі савецкай дэлегацыі правялі тры сустрэчы з групай П. Крачэўскага. А. Цвікевіч, Л. Заяц і У. Пракулевіч падчас апошняй сустрэчы з 3. Жылуновічам заявілі, што не супраць адмовіцца ад свайго мінулага, калі ім будзе прадстаўлена права на ўезд у БССР ${ }^{40}$.

Сустрэчы Я. Купалы, 3. Жылуновіча, М. Чарота з пражскімі беларускімі студэнтамі яшчэ больш замацавалі сярод значнай часткі апошніх прасавецкія настроі і разуменне Менска як цэнтра па аб'яднанні беларускіх зямель.

На нарадзе прадстаўнікоў ад БССР і паўнамоцных прадстаўнікоў CССР у Польшчы, Латвіi, Літве і Чэхаславакіi, якая адбылася 10 кастрычніка 1925 года пры НКЗС СССР, была ўзгоднена неабходнасць далейшай падтрымкі беларускага руху ў адзначаных вышэй краінах 3 мэтай накіравання яго ў патрэбнае для БССР рэчышча нацыянальна-рэвалюцыйнага руху ${ }^{41}$.

Актыўная дзейнасць ЦК КП(б)Б па развіцці руху прасавецкай арыентацыі ў 1925 годзе дала плён. У параўнанні з 1924 годам, на працягу 1925-га шэрагі пражскіх беларускіх прасавецкіх арганізацый выраслі ў некалькі разоў. У канцы 1925 года ў Саюз студэнтаў-грамадзян БССР уваходзілі ўжо 15 чалавек, а ў «Грамаду» - $24^{42}$.

У тэзісах ЦК КП(б)Б «Беларускі рух за кардонам», складзеных 16 кастрычніка 1925 года, былі канкрэтызаваны асноўныя кірункі работы сярод беларускіх арганізацый у Польшчы, Латвіi, Літве

${ }^{39}$ Идеологическая деятельность..., с. 171; У. Ляхоўскі, Грамадска-культурная чьнннасиь..., с. 24.

${ }^{40} \Gamma$. Муха-Мухновский, op. cit., с. 97.

${ }^{41}$ Ibidem, c. 214.

42 Знешняя палітыка..., с. 184-191. 
i Чэхаславакіi. Так, планавался працягваць разлажэнне і драбленне беларускай эміграцыі ў гэтых краінах, не дапускаючы стварэння альтэрнатыўных БССР эміграцыйных цэнтраў.

Канкрэтнай задачай работы сярод беларусаў у ЧСР стала ўмацаванне ўплыву ў «Грамадзе», праз якую павінна была праводзіцца далейшая вярбоўка беларускіх студэнтаў. За ЦК КП(б)Б прызнавалася вызначальная роля (ва ўзгадненні з Калегіяй НКЗС СССР і ЦК РКП(б)) у кіраванні беларускім нацыянальна-рэвалюцыйным рухам за мяжой. Прычым, рашэнні павінны былі выконвацца паўнамоцнымі прадстаўнікамі СССР за мяжой па ўказаннях, атрыманых ад НКЗС ССCР ${ }^{43}$.

8 снежня 1925 года старшыня СНК БССР Я. Адамовіч накіраваў у НКЗС СССР каштарыс фінансавання беларускай працы за мяжой. Згодна $з$ гэтым дакументам, у 1926 годзе на Чэхаславакію планавалася выдзеліць 12 тысяч рублёў (у месяц - адну тысячу), якія прызначаліся на падтрымку прасавецкіх студэнцкіх арганізацый і субсідзіраванне прэсы. Напрыклад, на беларускую працу ў Латвіі і Літве адпаведна прызначалася 18 і 33,6 тысячы рублёў ${ }^{44}$. На закрытым пасяджэнні Бюро ЦК КП(б)Б, якое праводзілася 11 снежня 1925 года, было вырашына прафінансаваць прасавецкіх студэнтаў у Празе на суму 150 долараў (на тры месяцы $)^{45}$.

Беларуская дыяспара ў ЧСР неадназначна паставілася да вынікаў II Усебеларускай канферэнцыі, на якой быў ліквідаваны ўрад БНР, а Менск прызнаны адзіным цэнтрам па аб'яднанні ўсіх беларускіх зямель. У Берліне прысутнічала пяць дэлегатаў ад беларускай калоніі ў ЧСР, а ініцыятыўную групу па падрыхтоўцы канферэнцыі ўзначальваў старшыня Беларускай рады ў Празе Л. Заяц ${ }^{46}$. Частка пражскіх дэлегатаў падтрымала пазіцыю А. Цвікевіча па ліквідацыі

${ }^{43}$ Идеологическая деятельность ..., с. 196-198.

${ }^{44}$ Нацыянальны архіў Рэспублікі Беларусь (НАРБ), ф. 4-п, воп. 1, спр. 2007, арк. 6-7.

${ }^{45}$ Ibidem, арк. 74.

${ }^{46}$ БДАМЛіМ, ф. 3 , воп. 1, спр. 184, арк. 24 адв. 
ўрада БНР, але большасць выступіла катэгарычна супраць. Так, дэлегаты АБСА дэманстратыўна пакінулі канферэнцыю, пасля чаго на агульным сходзе АБСА прынялі адпаведную рэзалюцыю, у якой «была зганьблена палітычная спекуляцыя „бывших людей”» ${ }^{47}$.

Найбольшы рэзананс вынікі II Усебеларускай канферэнцыі атрымалі на агульным гадавым сходзе Беларускай рады ў Празе, які праходзіў 12 снежня 1925 года. Група Л. Зайца спрабавала замацаваць берлінскі поспех і ўвесці ў кіраўніцтва арганізацыі як мага больш сваіх прыхільнікаў. Пасля заслухоўвання справаздачы аб дзейнасці рады за мінулы год слова ўзяу В. Грышкевіч, які асудзіў дзейнасць трох членаў арганізацыі (Л. Зайца, У. Пракулевіча і Я. Дыліса) на II Усебеларускай канферэнцыі, прапанаваўшы прыняць рэзалюцыю аб іх выключэнні з Беларускай рады ў Празе. У. Жылка выступіў супраць вынясення такой рэзалюцыі. Далей слова было дадзена У. Пракулевічу, які патлумачыў, што іх з Л. Зайцам выступленне ў Берліне было зроблена для кансалідацыі беларускай інтэлігенцыі і наладжвання кантактаў з інтэлігенцыяй на бацькаўшчыне. Пасля $з$ вельмі жорсткай крытыкай у адрас групы Л. Зайца выказаўся В. Захарка, назваўшы яе «здраднікамі народа». Большасць прысутных не пажадала выслухоўваць адказ «абвінавачаных». Па выніках галасавання (10 супраць 7) Л. Заяц, У. Пракулевіч і Я. Дыліс былі выключаны з арганізацыі ${ }^{48}$.

У сваім апошнім слове Л. Заяц, тлумачачы свае дзеянні ў Берліне, сярод іншага, сказаў сваім апанентам наступнае: «Што будзеце рабіць, калі скончыце вучобу? Будзеце хутчэй займаць месцы мясцовай інтэлігенцыі і будаваць рэспублікі за куфлем піва?! Абставіны нагэтулькі змяніліся, што тут немагчыма ствараць незалежнасць рэспублікі, працы вельмі шмат, але на радзіме, у асяроддзі ўласнага народа». Пасля прамовы Л. Заяц са сваімі аднадумцамі, «спяваючы

\footnotetext{
${ }^{47}$ В. Лаўскі, op. cit., с. 23.

${ }^{48}$ Дабрасельскі, op. cit., с. 3; AMZV, II Sekce politická, karton 390, č. 26645.
} 
нацыянальны гімн», пакінулі памяшканне ${ }^{49}$. У новы прэзідыум Беларускай рады ў Празе былі абраны В. Захарка (старшыня), М. Вяршынін, В. Лаўскі, В. Грышкевіч і М. Каберац.

Такім чынам, на агульным сходзе Беларускай рады ў Празе адбыўся канчатковы ідэалагічна-арганізацыйны падзел дыяспары на прыхільнікаў БССР і БНР. 3 гэтага часу абедзве групы дыяспары суіснавалі паралельна, звёўшы да мінімуму кантакты між сабою.

Наўмысная ізаляцыя: дзейнасць прасавецкіх арганізацый у другой палове 1920-х гадоў

Пасля сходу Беларускай рады ў Празе ў снежні 1925 года абедзве ідэалагічныя плыні дыяспары (нацыянальна-дэмакратычная і прасавецкая) больш не імкнуліся да прамога сутыкнення ў межах асобнай арганізацыі, а заняліся кансалідацыяй сваіх прыхільнікаў і павялі актыўную працу сярод беспартыйных беларусаў з мэтай ix далучэння да свайго палітычнага лагера. Большы патэнцыял, азіраючыся на поспехі беларусізацыі і ўлічваючы заняпад структур БНР, мелі прасавецкія аб'яднанні ў ЧСР, якія атрымлівалі шчодрае фінансаванне праз прадстаўніцтва СССР у ЧСР.

Вясной 1926 года жыццё «беларускага паступовага студэнства ў Празе» канцэнтравалася ў дзвюх арганізацыях. Саюз студэнтаўграмадзян аб'ядноўваў 18 сяброў, якія «па сканчэньні вышэйшай школы ў Чэхіі думаюць ехаць у С.C.C.Р., каб там служыць на карысьць працоўнага народу». Культурна-асветную дзейнасць праводзіла таварыства «Грамада», што аб'ядноўвала 30 чалавек ${ }^{50}$.

Шмат часу прасавецкія студэнты праводзілі ў клубе-чытальні «беларускага паступовага студэнцтва» ў Празе, што быў адкрыты

${ }^{49}$ Národní archiv České Republiky (NAČR), f. 207, karton 406, sign. 207-406-21, 1. 8-12.

${ }^{50}$ Жыщьиё беларускага паступовага студэнства у Празе, «Прамень» 1926, № 1, c. 30-31. 
9 кастрычніка 1925 года пры фінансавай падтрымцы савецкага прадстаўніцтва ў ЧСР. У клуб рэгулярна паступалі беларускія перыядычныя выданні з Латвіі, БССР і рускамоўныя газеты з СССР. Да таго ж, гэта асветная ўстанова мела ўласную бібліятэку, якой карысталіся ўсе беларусы, незалежна ад палітычных поглядаў ${ }^{51}$.

Са снежня 1925 года пачало дзейнічаць пражскае аддзяленне аб'яднання паэтаў і пісьменнікаў «Маладняк» на чале з У. Жылкам $^{52}$. Праца гэтай творчай суполкі, згодна 3 пастановай бюро ЦК КП(б)Б, каардынавалася супрацоўнікам паўпрэдства СССР у ЧСР, адказным за беларускую дзейнасць. Пражскія «маладнякоўцы» павінны былі ўзгадняць 3 паўпрэдствам «усе выступленні, якія насілі характар палітычнай дэманстрацыі ў адносінах да БССР» ${ }^{53}$. Стварэнне аддзялення «Маладняка» і арганізацыя клуба-чытальні істотна павялічылі арганізацыйныя магчымасці прасавецкай групы, яе інфармацыйна-прапагандысцкі патэнцыял.

Нягледзячы на поспех Берлінскай канферэнцыі, фінансаванне прасавецкіх беларускіх арганізацый у Празе было працягнута і далей. Праўда, грошай выдаткоўвалі менш у параўнанні з 1925 годам. Так, у 1927 годзе на Чэхаславакію меркавалася выдзеліць 6 тысяч рублёў (500 у месяц). Гэтыя сродкі павінны былі расходавацца на падтрымку часопіса «Прамень» і беларускіх прасавецкіх студэнцкіх арганізацый у Празе, сябры якіх, як адзначалася, «за выяўленне сваёй палітычнай фізіяноміі ўжо пазбаўлены субсідыі чэшскага ўрада» ${ }^{54}$. Паводле У. Ляхоўскага, фінансаванне часопіса «Прамень» пачалося яшчэ ў 1925 годзе, калі паводле рэзалюцыі Бюро ЦК КП(б)Б на выданне гэтага друкававанага органа праз прадстаўніцтва СССР у ЧСР было выдаткавана 2 тысячы рублёў у чырвонцах ${ }^{55}$.

\footnotetext{
51 Эміграцьыя, с. 31.

${ }^{52}$ Ibidem, c. 31.

${ }^{53}$ НАРБ, ф. 4-п, воп. 1, спр. 2536, арк. 74.

54 Знешняя палітыка..., с. 214-215.

${ }^{55}$ У. Ляхоўскі, Ад гоманаўц̧аў..., с. 397.
} 
Як бачым, ключавая роля ў папулярызацыі прасавецкіх настрояў сярод беларускай дыяспары адводзілася друкаванаму слову. Першы нумар часопіса прасавецкай моладзі «Прамень» пабачыў свет у маі 1926 года. У адпаведнасці з законамі ЧСР, адказным рэдактарам і выдаўцом часопіса стаў грамадзянін ЧСР Іван Сэканіна ${ }^{56}$. Гэта выданне асвятляла становішча беларусаў у Заходняй Беларусі і Латвіi, а таксама інфармавала аб культурнай працы, якая праводзілася ў Савецкай Беларусі. «Прамень» прасоўваў ідэю аб тым, што «заветная думка беларускае інтэлігенцыі - Беларуская дзяржава, праўда, Савецкая, зьдзейсьнілася воляю пралетарыяту» ${ }^{57}$.

Часопіс «Прамень» стаў «трыбунай прапаганды сацыялістычных прынцыпаў для ўсіх тых, якія ня выпрацавалі сабе яснага сьветагляду на сучаснае становішча, але шчыра і чэсна імкнуцца знайсьці сваё мейсца ў барацьбе старога сьвету, сьвету гвалту і эксплёатацыі з новымі прынцыпамі - вызваленьня і панаваньня працуючых ${ }^{58}$. М. Чмарава правільна адзначыла, што на старонках «Прамяня» дапускалася шмат перабольшванняў і хваравіта ўспрымалася тое станоўчае, што ўдалося зрабіць эміграцыі ${ }^{59}$.

Другі нумар «Новага прамяня» (лістапад 1926 года) быў прысвечаны праблемам тагачаснай чэшскай культуры і аналізу літаратурнага працэсу ў Заходняй Беларусі ${ }^{60}$. Трэці нумар часопіса (пад назвай «Наш прамень») выйшаў у 1927 годзе і быў амаль цалкам прысвечаны палітыка-эканамічным праблемам. У нумары ўзма-

${ }^{56}$ Іван Сэканіна (1900-1940), чэшскі юрыст, ідэйны таварыш Ю. Фучыка. 3'яўляўся адказным рэдактарам розных часопісаў прасавецкай арыентацыі, напрыклад, друкаванага органа Саюза студэнтаў-грамадзян Украінскай Савецкай Сацыялістычнай Рэспублікі ў Чэхаславакіі «Вперед» (1928-1930), а таксама выконваў ролю шэфа сумеснага друкаванага органа Саюза студэнтаў-грамадзян РСФСР і Саюза студэнтаў грамадзян УССР «Наше знамя» («Наш прапор») у 1924-1926 гадах (М. Чмарава, op. cit., с. 18).

${ }^{57}$ Ад рэдакиыыi, «Прамень» 1926, № 1, с 1.

${ }^{58}$ Ibidem, c. 3.

${ }^{59}$ М. Чмарава, op. cit., с. 19.

${ }^{60} \mathrm{Ibidem}$, c. 20. 
цнілася ідэалізацыя, некрытычнае стаўленне да таго, што адбывалася ў БССР. Тым не менш, часопіс стаў самым аўтарытэтным выданнем беларускага студэнцтва ў Празе ${ }^{61}$ і паспрыяў папулярызацыі прасавецкіх настрояў сярод беларускай моладзі.

Разам 3 асвятленнем бягучых палітычных падзей беларускія прасавецкія студэнты значную ўвагу надавалі пытанням чэхаславацка-беларускіх літаратурных сувязей, развіцця беларускай савецкай літаратуры. На старонках часопіса «Прамень» рэгулярна змяшчаліся пераклады твораў чэхаславаціх аўтараў (І. Волькера, Ю. Фучыка, К. Тэйге). М. Чмарава лічыць, што менавіта дзякуючы часопісу «Прамень» былі наладжаны цесныя кантакты 3 чэхаславацкімі і нямецкімі пралетарскімі пісьменнікамі і левымі інтэлектуальнымі коламі ЧСР, а таксама супрацоўніцтва беларускіх прасавецкіх студэнтаў з перыядычнымі выданнямі ЧСР 22.

Марудна рухалася справа з афіцыйным зацвярджэннем галоўнай прасавецкай арганізацыі беларускай моладзі ў Празе - Саюза студэнтаў-грамадзян БССР. Чэхаславацкія ўлады афіцыйна зацвердзілі саюз толькі 23 чэрвеня 1926 года. Згодна са статутам саюз з'яўляўся апалітычнай арганізацыяй ${ }^{63}$. Галоўнай мэтай стала дапамога маладым людзям пасля сканчэння вучобы праз прадстаўніцтва СССР атрымаць савецкае грамадзянства і дазвол на уеезд у БССР. Дзейнасць саюза, як і «Грамады», працякала пад пільным наглядам з боку Марксісцкай групы. Усе рашэнні спачатку абмяркоўваліся ў групе, а пасля ўжо выносіліся на разгляд саюза.

На ўстаноўчым сходзе Саюза студэнтаў-грамадзян БССР, які праходзіу 30 лістапада 1926 года, былі працягнуты паўнамоцтвы старшыні арганізацыі М. Каўцэвіча. У прэзідыум абралі А. Карповіча, М. Пілецкага, М. Рагулю, М. Шыманку. М. Каўцэвіч з не-

\footnotetext{
${ }^{61}$ Ibidem, c. 22.

${ }^{62}$ Ibidem, c. 22, 23.

${ }^{63}$ Archiv hlavního města Prahy (AhlmP), f. SK X/345 „Svaz studujicích vysokých škol - občanů B.S.S.R.”, č. 260486.
} 
вялікім перапынкам займаў пасаду старшыні саюза да 1930 года. 3 лістапада 1927 да красавіка 1928 года арганізацыю ўзначальваў М. Пілецкі. У саюз уваходзілі пераважна беларускія студэнты Пражскай політэхнікі. Да 1927 года саюз налічваў каля 30-35 сяброў, пазней колькасць членаў арганізацыі не перавышала 15 чалавек ${ }^{64}$.

Істотным складальнікам дзейнасці беларускіх прасавецкіх аб'яднанняў у Празе была крытыка польскай палітыкі ў дачыненні да насельніцтва Заходняй Беларусі. Беларускія прасавецкія студэнты рэгулярна прымалі ўдзел у мерапрыемствах антыпольскай накіраванасці, арганізаваных левымі коламі ЧСР 65 .

Пасля разгрому польскімі ўладамі БСРГ, 21 студзеня 1927 года беларускія і ўкраінскія прасавецкія студэнты «склалі пратэст супроць белага тэрору ў Польшчы» ${ }^{66}$. Амаль палова матэрыялаў часопіса «Наш прамень» (чэрвень 1927 года) была прысвечана агляду дыскрымінацыйнай палітыкі афіцыйнай Варшавы ў дачыненні да беларусаў у Заходняй Беларусі. Вясной 1928 года Прагу наведалі 3. Жылуновіч і С. Некрашэвіч, якія пры падтрымцы чэхаславацкай левай грамадскасці арганізавалі мітынг у падтрымку БСРГ. У мерапрыемстве прынялі ўдзел і беларускія прасавецкія студэнты ${ }^{67}$.

Кіраўніцтва прасавецкіх беларускіх арганізацый не толькі аператыўна рэагавала на антыбеларускую палітыку польскіх улад, але і актыўна выкарыстоўвала патэнцыял культурных мерапрыемстваў. У такіх сустрэчах, як правіла, прымалі ўдзел вядомыя чэхаславацкія культурныя дзеячы з левымі поглядамі і прадстаўнікі савецкага прадстаўніцтва ў ЧСР. Гэтыя вечары, фінансаваныя праз савецкае прадстаўніцтва, арганізоўваліся на высокім узроўні і мелі на мэце знаёмства чэхаславацкага грамадства з беларускай савецкай культурай, пераконвалі суайчыннікаў у тым, што ў савецкай дзяржаве

\footnotetext{
${ }^{64}$ В. Лаўскі, op. cit., с. 22.

${ }^{65}$ Ibidem, c. 76-77.

${ }^{66}$ Хроніка. Чэхаславакія, «Наш прамень» 1927, № 1, с. 75.

${ }^{67}$ НАРБ, ф. 4-п, воп. 1, спр. 2498, арк. 27.
} 
адбываецца сапраўдны рэнесанс нацыянальнай беларускай культуры.

Важнай падзеяй у жыцці беларускай дыяспары стала святкаванне 20-годдзя творчай дзейнасці Я. Коласа, арганізаванае па ініцыятыве пражскага «Маладняка». Адпаведная «акадэмія» (канцэрт) адбылася 13 студзеня 1927 года. У сустрэчы прыняў удзел 3. Неедлы ${ }^{68}$, выступіўшы 3 дакладам аб творчасці Я. Коласа. Чэшскі дзіцячы хор пад кіраўніцтвам Ф. Бакулы і Інтэрнацыянальны студэнцкі хор праспявалі беларускія песні. На вечары таксама выступіў саветнік прадстаўніцтва СССР у ЧСР Н. Калюжны, які падкрэсліў высокі ўзровень развіцця беларускай культуры ў БССР ${ }^{69}$.

3 чэрвеня 1927 года пражскі «Маладняк» разам з Цэнтральным саюзам чэхаславацкага студэнцтва арганізаваў чарговы вечар беларускай песні ${ }^{70}$. Мерапрыемства адкрыў 3 . Неедлы, які прачытаў рэферат аб беларускай песні. 15 беларускіх песень праспяваў чэшскі дзіцячы хор пад кіраўніцтвам Ф. Бакулы ${ }^{71}$.

Прасавецкія беларускія студэнты ў другой палове 1920-х - пачатку 1930-х гадоў актыўна друкавалі артыкулы па беларускай праблематыцы ў чэхаславацкіх перыядычных выданнях („С̆уn”, „Literarní noviny”, „Kmen”), тым самым адкрываючы для чэхаславацкага грамадства свет беларускай савецкай культуры. М. Шыманка і Г. Муха былі пазаштатнымі супрацоўнікамі друкаванага органа КПЧ „Rude pravo”72. Прасавецкія студэнты паказвалі афіцыйную беларускую савецкую літаратуру ў самым пазітыўным выглядзе.

68 Здэнак Неедлы (1878-1962) - чэхаславацкі вучоны і грамадскі дзеяч. Ініцыятар стварэння ў 1925 годзе і першы старшыня Таварыства эканамічнага і культурнага збліжэння з новай Расіяй (з 1931 года - Таварыства эканамічнага і культурнага збліжэння з СССР).

${ }^{69}$ Хроніка. Чэхаславакія, с. 75, 77-78.

70 Эміграцьия, с. 31.

${ }^{71}$ Хроніка. Чэхаславакія, с. 78.

${ }^{72}$ Г. Муха-Мухновский, op. cit., с. 100; М. Чмарава, op. cit., с. 102-103, 105-106. 
М. Шыманка не толькі актыўна публікаваўся ў чэхаславацкіх часопісах, але і папулярызаваў чэхаславацкую літаратуру ў беларускіх савецкіх выданнях. У 1927-1929 гадах практычна кожны нумар «Полымя» змяшчаў пераклады чэхаславацкіх пісьменнікаў, агляды чэхаславацкай літаратуры ${ }^{73}$.

У пачатку 1928 года, аналізуючы дзейнасць афіцыйнага Менска сярод беларускай эміграцыі за 1927 год, у КП(б)Б прыйшлі да вываду, што «працэс распаду эмігранцкіх партый і арганізацый дасягнуў мяжы, таму і эміграцыя як рэвалюцыйны і контррэвалюцыйны фактар перастае іграць ролю ў беларускім руху за кардонам» ${ }^{74}$. Адпаведна, было істотна зменшана фінансаванне дзейнасці прасавецкіх аб'яднанняў беларускіх эмігрантаў.

У 1925 годзе беларускія студэнты, стыпендыяты чэхаславацкага ўрада, пачалі атрымліваць дыпломы. Большасць выпускнікоў вярталіся на бацькаўшчыну. Сябры прасавецкіх аб'яднанняў выязджалі пераважна ў БССР, меншая частка рээмігрыравала ў Польшчу. Прытоку значных груп новых беларускіх студэнтаў у Прагу не было ${ }^{75}$. Натуральна, у сувязі з імклівым змяншэннем дыяспары многія арганізацыі спынілі сваю дзейнасць, а тыя, што працягвалі існаваць, праяўлялі мінімальную актыўнасць.

У канцы 1920-х гадоў у Празе засталася толькі адна саветафільская арганізацыя - Саюз студэнтаў-грамадзян БССР ${ }^{76}$. Уся праца саюза ў першай палове 1929 года абмежавалася правядзеннем некалькіх лекцый. На той час у аб'яднанні налічвалася ўсяго 10 сяброў77.

Нарастанне аўтарытарных тэндэнцый у кіраўніцтве БССР і палітычныя рэпрэсіі супраць прадстаўнікоў інтэлігенцыі ў канцы

${ }^{73}$ Ibidem, c. 101, 105.

${ }^{74}$ Знешняя палітыка Беларусі. Зборнік дакументаў $і$ матэрыялаў. Т. 3, скл.: У. Міхнюк; рэдкал.: У. Ракашэвіч і інш., Мінск 2001, с. 176.

75 Пасля нармалізацыі польска-чэхаславацкіх адносін у красавіку 1925 года было спынена выдзяленне стыпендый для беларускай моладзі з Польшчы.

${ }^{76}$ Беларускія студэнты ў Чэхаславаччыне, «Беларус» 1973, № 195, с. 6.

${ }^{77}$ NAČR, f. 207, karton 419, sign. 71. 
1920-х - 1930-х гадах паўплывалі на адыход ад працы ў прасавецкіх арганізацыях часткі ранейшых іх прыхільнікаў, а таксама прывялі да канчатковай кампраметацыі зменавехаўскага руху сярод неангажыраваных у дзейнасць прасавецкіх арганізацый прадстаўнікоў беларускай дыяспары ў Чэхаславакіi. У пачатку 1930-х гадоў у сувязі з рээміграцыяй большай часткі сваіх сяброў Саюз студэнтаў-грамадзян БССР спыніў дзейнасць ${ }^{78}$.

Лёсы актывістаў пражскіх беларускіх прасавецкіх арганізацый пасля вяртання на бацькаўшчыну

Лёсы большасці лідараў пражскіх беларускіх прасавецкіх аб'яднанняў вельмі падобныя. Гэтых людзей ядналі вера ў савецкую ідэю, нерэалізаванасць сваіх талентаў у поўнай меры, пакуты ў сталінскіх лагерах i, як правіла, заўчасная смерць.

Тыя, хто вярнуўся ў Заходнюю Беларусь, далучыліся да рэвалюцыйна-вызваленчага руху, увайшлі ў кіраўніцтва Камуністычнай партыі Заходняй Беларусі, БСРГ, «Змагання». Тыя, хто перабраўся ў БССР, занялі пасады ў розных беларускіх савецкіх установах. У 1930-я гады большасць былых пражан у БССР рэпрэсіравалі (пераважна па сфабрыкаванай НКУС справе Беларускага нацыянальнага цэнтра (БНЦ)).

У 1926 годзе з Прагі ў Заходнюю Беларусь выехалі адны з лідараў пражскага беларускага прасавецкага студэнцтва Ігнат Дварчанін і Ян Казімір Бабровіч. Я. Бабровіч актыўна ўключыўся ў працу КПЗБ, быў кааптаваны ў ЦК гэтай партыі, стаў прадстаўніком КПЗБ пры ЦК БСРГ, рэдагаваў некалькі грамадоўскіх газет, быў абраны кандыдатам у члены ЦК КПП. У снежні 1928 года Я. Бабровіча арыштавалі і прыгаварылі да 15 гадоў турмы. У верасні 1932 года ў выніку абмену палітвязнямі ён пераехаў у СССР. У ка-

${ }^{78}$ AhlmP, f. SK X/345 „Svaz studujicích vysokých škol - občanů B.S.S.R.”, bez katalogizačního čísla. 
стрычніку 1933 года быў арыштаваны па справе БНЦ. Памёр у 1943 годзе ў Северадзвінскім лагеры (Архангельская вобласць Расіi).

Пасля вяртання ў Вільню І. Дварчанін уступіў у БСРГ, быў цесна звязаны з яе кіраўніцтвам. У 1928 годзе І. Дварчаніна абралі дэпутатам Сейма Польшчы. У Сейме ён разам з іншымі дэпутатамі стварыў фракцыю - Беларускі работніцка-сялянскі пасольскі клуб «Змаганне», які фактычна працягваў дзейнасць БСРГ. У 1930 годзе I. Дварчаніна арыштавалі і прыгаварылі да васьмі гадоў турмы. Як і Я. Бабровіч, у верасні 1932 годзе ён пераехаў у БССР. У верасні 1933 года па справе БНЦ быў арыштаваны органамі НКУС БССР. У снежні 1937 года І. Дварчаніна расстралялі.

У 1930 годзе ў Заходнюю Беларусь вярнуўся Ю. Муха. Менавіта ён ад ЦК КПЗБ каардынаваў дзейнасць «Змагання». У 1931 годзе Ю. Муху арыштавалі. У 1932 годзе (скарэй за ўсё ў выніку абмену палітвязнямі паміж Польшчай і СССР) пераехаў у СССР. Праз год яго арыштавалі па справе БНЦ. У ГУЛАГу Ю. Муха правёў 13 гадоў. Яму пашчасціла выжыць. Але нават пасля ўсяго перажытага ён застаўся верны «ленінскім ідэям» ${ }^{79}$.

У Польшчу выехаў і адзін з лідараў Марксісцкай групы Мікалай Верамей. Ён удзельнічаў у падрыхтоўцы выбараў у Сейм, друкаваў лістоўкі, арганізоўваў беларускія школы ў Заходняй Беларусі. У 1930 годзе быў перапраўлены ў БССР. У 1930 годзе арганізаваў і ўзначаліў Энергетычны інстытут у Менску. У 1933 годзе М. Верамея арыштавалі па справе БНЦ. Загінуў у 1937 годзе ў Хабараўскім краі Pacii.

У. Жылка ў 1926 годзе ўдзельнічаў у Акадэмічнай канферэнцы па рэформе беларускага правапісу і азбукі ў Менску, пасля якой застаўся ў сталіцы БССР, прыняўшы савецкае грамадзянства. У ліпені 1930 года па справе Саюза вызвалення Беларусі У. Жылку

79 Падрабязней пра Ю. Муху гл.: А. Пашкевіч, Справа «Беларускага наџыянальнага иэнтру» паводле сведчанняу быльх актывістаў Kампартыі Заходняй Беларусі, «Спадчына» 2006, № 1, с. 102-116. 
арыштавалі і прыгаварылі на пяць гадоў ссылкі ў г. Уржум Ніжагародскага краю Расіi. Там у 1933 годзе ён і памёр.

Шляхам У. Жылкі пайшоў і адзін з кіраўнікоў Саюза студэнтаў-грамадзян БССР Міхаіл Каўцэвіч. Ён у 1930 годзе пераехаў у Менск і стаў працаваць у фізіка-тэхнічным інстытуце Беларускай акадэміі навук (БАН). М. Каўцэвіча арыштавалі ў верасні 1937 года, а ў кастрычніку расстралялі.

Брат I. Дварчаніна Іларыён пасля заканчэння Пражскай політэхнікі адразу паехаў у Савецкую Беларусь. І. Дварчанін працаваў намеснікам дырэктара Беларускага дзяржаўнага паляўнічага запаведніка. У 1933 годзе па справе БНЦ быў арыштаваны. Загінуў у зняволенні.

У БССР з Прагі накіраваўся і Мікола Шыманка. У Менску ён уладкаваўся на працу ў БАН. У 1935 годзе М. Шыманку арыштавалі і асудзілі на пяць гадоў лагераў за «антысавецкую агітацыю». У сакавіку 1940 года вызвалілі. М. Шыманка выжыў. У 1963 годзе ў адным са сваіх лістоў да вучонага сакратара Дзяржаўнага літаратурнага музея Янкі Купалы ў Мінску А. Есакова М. Шыманка пісаў наступнае: «Мы ўсе настолькі слепа верылі ўсяму савецкаму - савецкай справядлівасці, савецкім законам, што паведамленне аб самагубстве Янкі Купалы ${ }^{80}$ лічылі за правакацыйны выпад ворагаў сав. улады. Аднак не на нашым баку аказалася праўда, а на баку клерыкалаў. У мяне, напрыклад, ружовыя акуляры ў справе Купалы разбіліся ўшчэнт у 1931 годзе, калі я прыехаў з Прагі ў Менск» ${ }^{81}$.

Таксама трагічна скончыліся жыцці сяброў урада БНР, якія пасля Берлінскай канферэнцыі перабраліся ў Менск. Л. Заяц памёр ва ўфімскай турме ў 1935 годзе. А. Цвікевіча і У. Пракулевіча расстралялі ў 1938 годзе.

Невядома, што пасля выезду з Прагі стала з іншымі ўдзельнікамі беларускіх прасавецкіх аб’яднанняў.

${ }^{80}$ Маецца на ўвазе спроба самагубства Янкі Купалы ў 1930 годзе.

${ }^{81}$ М. Трус, Захаванасиьь традыцыый, пераемнасиьь клопатаў. Слова і пасляслоўе пра візіт Янкі Купалы у Чэхаславакію у 1927 г., «Роднае слова» 2012, № 6, с. 6. 
Архіўныя крыніцы

Archiv hlavního města Prahy, f. SK X/345 „Svaz studujicích vysokých škol občanů B.S.S.R.”, č. 260486.

Archiv Ministerstva zahraničních věcí České Republiky, II Sekce politická, karton 241, č. 106650; karton 390, č. 26645; karton 450, č. 107866.

Národní archiv České Republiky, f. 207, karton 406, sign. 207-406-21, 1. 8-12; karton 419, sign. 71.

Беларускі дзяржаўны архіў-музей літаратуры і мастацтва, ф. 3, воп. 1, спр. 181, арк. 35-37; спр. 184, арк. 24 адв.

Нацыянальны архіў Рэспублікі Беларусь, ф. 4-п, воп. 1, спр. 2007, арк. 6-7; спр. 2498, арк. 27; спр. 2536, арк. 74.

\section{Літаратура}

A. A., Kryvickaje (Biełaruskaje) Kulturnaje Tawarystwa d-ra Franciška Skaryny, „Krynica” 1925, nr 28.

Kolenovská D., Běloruská emigrace v Československu (1918-1939), „Soudobé dějiny" 2007, nr 1.

Aд рэдакиыi, «Прамень» 1926, № 1 .

Архівы Беларускай Народнай Рэспублікі. Т. 1. Кн. 2. Фонд № 582 Дзяржайнага Архіву Літвы («Рада Міністрай Беларускай Народнай Рэспублікі»), укл. С. Шупа, Vilnius, New York, Мінск, Praha 1998.

Баршчэўскі А., Беларуская эміграиыйная пісьмовасиь, Warszawa 2004.

Беларускія студэнты у Чэхаславаччыне, «Беларус» 1973, № 195.

Дабрасельскі, Беларуская калёнія ў Празе-Чэшскай, «Сялянская ніва» 1926, № 3.

Жук-Грышкевіч Р., Жыцьиеё Вінцэнта Жук-Грышкевіча, Toronto 1993.

Жыцьцё беларускага паступовага студэнства ў Празе, «Прамень» 1926, № 1. Заяц Л., Беларусы у Чэхаславакіi, «Савецкая Беларусь» 1926, № 143.

Знешняя палітыка Беларусі. Зборнік дакументаў і матэрыялаў. Т. 2, скл.: У. Міхнюк; рэдкал.: І. Антановіч і інш., Мінск 1999.

Знешняя палітыка Беларусі. Зборнік дакументаў і матэрыялай. Т. 3, скл.: У. Міхнюк; рэдкал.: У. Ракашэвіч і інш., Мінск 2001.

Идеологическая деятельность Компартии Белоруссии. 1918-1945. Сборник документов. Ч. 1, сост.: Н. С. Сташкевич, редкол.: Р. П. Платонов и др., Минск 1990.

Калеснік У., Ветразі Адысея, Мінск 1978. 
Калеснік У., Пражскі эпісталярый [у:] Усё чалавечае: літаратурныя партрэты, Мінск 1993.

Калеснік У., Пражскі эпісталярый, «Полымя» 1990, № 9, 10.

Лаўскі В., 3 жыцьия беларускага студэнства на чужыне, «Студэнская думка» 1928 , № 1.

Лісты Уладзіміра Жылкі да Антона Луиякевіча, публ., падрыхт. тэксту, камент. А. Сідарэвіча [у:] Шляхам гадоў: гісторыка-літаратурны зборнік, укл. Я. Янушкевіч, рэдкал.: Г. Кісялеў і інш., Мінск 1994.

Ляхоўскі У., Ад гоманаўиаў да гайсакоў. Чыннасиь беларускіх маладзёвых арганізаиьий у 2-й палове ХІХ сm. - 1939 г., Białystok, Vilnius 2012.

Ляхоўскі У., Беларускія студэникія арганізаџылі у Чэхіі [у:] Эниылклапедыя гісторыі Беларусі. У 6 m. Т. 6. Кн. 2, Мінск 2003.

Ляхоўскі У., Грамадска-культурная чыннасиь беларускай дыяспары у Чэхаславакіi у 1921-1938 г2. [у:] Ёсиь на карие месиа... Грамадска-культурная чыннасиь беларускай і расійскай эмігращыі у Чэхаславакіі. 19211938. Каталог, укл. Т. Воранава, Мінск 2002.

Мирочицкий Л., Белорусско-чехословачкие культурные и научные связи, Минск 1981.

Місарэвіч Я., Каралёў М., І. С. Дварчанін: гісторыка-біяграфічны нарыс, Гродна 1995.

Муха-Мухновский Г., Пути-дороги, Минск 1973.

Пашкевіч А., Справа «Беларускага наџьяянальнага иээнтру» паводле сведчанняў былых актывістай Кампартыі Заходняй Беларусі, «Спадчына» 2006, № 1.

Траццяк С., Рэвалюиыйная хваля беларускай эміграцыі [у:] Гісторыя Белаpyci. Т. 5. Беларусь у 1917-1945 гz., рэдкал.: М. Касцюк і інш., Мінск 2007.

Трус М., Захаванасиь традыцый, пераемнасиь клопатай. Слова і пасляслоўе пра візіт Янкі Купальь у Чэхаславакію у 1927 г., «Роднае слова» 2012, № 6.

Хроніка, «Перавясла» 1923, № 1.

Хроніка, «Перавясла» 1924, № 2.

Хроніка. Чэхаславакія, «Наш прамень» 1927, № 1.

Ціхаміраў А., Эміграцыл [у:] Эниыклапедыя гісторыі Беларусі. У 6 m. Т. 6. Кн. 2, Мінск 2003.

Чмарава М., Шляхі уззаемнага пазнання: беларуская літаратура у Чэхаславакіi (1920-1945 г2.), Магілёў 2004.

Эмігращыя, «Прамень» 1926, № 1. 


\section{The activities of Belarusian pro-Soviet organizations in Czechoslovakia in the 1920s}

In 1920s Prague was the political, intellectual, academic, scientific and research center of Belarusians abroad. Hundreds of Belarusian students studied in Czechoslovakia, also Belarusian public and political figures lived and worked there. In 1920s ideas of Smenovekhovtsy have gained much popularity among Prague Belarusians. During this period in Prague were a number of Belarusian pro-Soviet organizations. The CP(b)B and Soviet representative in the Czechoslovak Republic effectively fulfill development of the movement pro-Soviet orientation among Belarusian emigrants. After graduating from high schools of the Czechoslovak Republic the majority of pro-Soviet Belarusian associations moved to the Belarusian SSR.

Keywords: Czechoslovakia, Belarusian diaspora, interwar period 